\title{
Nitrous oxide emissions in proportion to nitrification in moist temperate forests
}

\author{
Shaoyan Fan $\cdot$ Muneoki Yoh
}

Received: 28 December 2018/ Accepted: 9 March 2020/Published online: 3 April 2020

(C) The Author(s) 2020

\begin{abstract}
Chronic elevated nitrogen deposition has increased nitrogen availability in many forest ecosystems globally, and this phenomenon has been suggested to increase soil nitrification. Although it is believed that increased nitrogen availability would also increase nitrous oxide $\left(\mathrm{N}_{2} \mathrm{O}\right)$ emissions from forest ecosystems, its impact on $\mathrm{N}_{2} \mathrm{O}$ flux is poorly known. In this study, 3-years monitoring of $\mathrm{N}_{2} \mathrm{O}$ emissions was performed in a forested watershed receiving elevated nitrogen deposition and located in the suburbs of Tokyo, Japan. In addition, a comparative field survey was carried out in nine temperate forest sites with varying nitrogen availabilities. In the intensively studied forest site showing typical nitrogen saturation, the average annual $\mathrm{N}_{2} \mathrm{O}$ emissions from the whole watershed were estimated to be $0.88 \mathrm{~kg} \mathrm{~N} \mathrm{ha}^{-1}$ year $^{-1}$, comparable to the highest observed levels for temperate forests except for some very high emission sites in Europe. Although no correlation was found for humid spots with
\end{abstract}

Responsible Editor: Jacques C. Finlay.

S. Fan

United Graduate School of Agricultural Science, Tokyo University of Agriculture and Technology, Fuchu,

Tokyo, Japan

M. Yoh ( $\square)$

Institute of Agriculture, Tokyo University of Agriculture and Technology, Fuchu, Tokyo, Japan

e-mail: yoh@cc.tuat.ac.jp
WFPS $>60 \%$, a clear positive correlation was noted between $\mathrm{N}_{2} \mathrm{O}$ flux and net nitrification rate in situ for plots with water-filled pore space (WFPS) $<60 \%$. The $\mathrm{N}_{2} \mathrm{O}$ flux varied across nine forest sites almost in proportional to the stream water $\mathrm{NO}_{3}{ }^{-}$concentration in the watershed that ranged from 0.14 to $1.64 \mathrm{mg} \mathrm{N} /$ L. We conclude that $\mathrm{N}_{2} \mathrm{O}$ emissions are related to nitrification in moist temperate forest, which may be associated with the magnitude of nitrogen saturation.

Keywords Nitrous oxide - Nitrogen availability · Nitrogen saturation $\cdot$ Nitrification $\cdot$ Temperate forest

\section{Introduction}

Nitrous oxide $\left(\mathrm{N}_{2} \mathrm{O}\right)$, the third most influential greenhouse gas in global warming, is estimated to account for approximately $6 \%$ of the radiative forcing of the global climate (IPCC 2007). Atmospheric $\mathrm{N}_{2} \mathrm{O}$ concentrations have increased nearly linearly by approximately $0.8 \mathrm{ppb}$ year $^{-1}$ over the past few decades, from approximately $270 \mathrm{ppb}$ during the pre-industrial era to $327.1 \pm 0.1 \mathrm{ppb}$ in 2014 (WMO 2015). The current increase of atmospheric $\mathrm{N}_{2} \mathrm{O}$ has the potential to impact global climate in the next century (Shindell et al. 2009).

Temperate forests have been identified as a major source of $\mathrm{N}_{2} \mathrm{O}$ emissions (e.g., Brumme and Beese 
1992; Skiba et al. 1999). However, current estimates of $\mathrm{N}_{2} \mathrm{O}$ emissions from temperate forests vary markedly. Some forests show high emissions whereas others have negligible emissions. In several temperate forests in Europe receiving elevated levels of atmospheric nitrogen deposition, high annual $\mathrm{N}_{2} \mathrm{O}$ flux has been reported; e.g., 0.67-0.92 $\mathrm{kgN}_{2} \mathrm{O}-\mathrm{N}$ ha $^{-1}$ year ${ }^{-1}$ (Schmidt et al. 1988), 1.15-2.29 $\mathrm{kgN}_{2} \mathrm{O}-\mathrm{N} \mathrm{ha}^{-1}$ year $^{-1}$ (Pitcairn et al. 2002), and $2.6 \mathrm{kgN}_{2} \mathrm{O}-\mathrm{N}$ ha ${ }^{-1}$ year $^{-1}$ (Eickenscheidt et al. 2011). The highest $\mathrm{N}_{2} \mathrm{O}$ flux was observed in an $\mathrm{N}$-saturated forest site in Germany ('Sölling'), which has a particularly low pH of 3.5 (Eickenscheidt and Brumme 2013). To the contrary, low $\mathrm{N}_{2} \mathrm{O}$ emissions have been generally reported in temperate forests in North America; e.g., -0.03 to $0.06 \mathrm{kgN}_{2} \mathrm{O}-\mathrm{N} \mathrm{ha}^{-1}$ year $^{-1}$ (Castro et al. 1992) and 0.01-0.02 $\mathrm{kgN}_{2} \mathrm{O}-\mathrm{N}$ $\mathrm{ha}^{-1}$ year $^{-1}$ (Bowden et al. 1990). Due to the adoption of such variable fluxes in different forests to evaluate global emissions, current estimates of $\mathrm{N}_{2} \mathrm{O}$ emissions from temperate forests vary widely from 0.1 to $2.0 \mathrm{Tg}$ $\mathrm{N}_{2} \mathrm{O}-\mathrm{N}$ year $^{-1}$ (Brumme et al. 2005; IPCC 2001; Kroeze et al. 1999), implying significant uncertainty. It is important to understand the key factor associated with this gap in $\mathrm{N}_{2} \mathrm{O}$ emissions from forests.

It is generally thought that $\mathrm{N}_{2} \mathrm{O}$ emissions from soils are a result of either nitrification or denitrification (Bremner 1997). A factor affecting the major process responsible for $\mathrm{N}_{2} \mathrm{O}$ production is water-filled pore space (WFPS) (Bateman and Baggs 2005); nitrification is dominant for $\mathrm{N}_{2} \mathrm{O}$ production with WFPS $<$ $60 \%$, whereas denitrification becomes increasingly important when WFPS exceeds $60 \%$. These microbial processes are also controlled by soil chemical and physical properties, including the availability of mineral $\mathrm{N}$ and organic matter, $\mathrm{pH}$, and soil type, as well as climate-related soil properties, such as temperature and water content (e.g., Dalal et al. 2003; Skiba and Smith 2000; Bouwman et al. 2002). In addition, soil $\mathrm{C} / \mathrm{N}$ ratio is suggested as an important indicator for net nitrification and $\mathrm{N}_{2} \mathrm{O}$ emissions in forest ecosystems (e.g., Klemedtsson et al. 2005; Pilegaard et al. 2006; Gundersen et al. 2012).

Over several decades, human activity has dramatically increased reactive nitrogen emissions to the global atmosphere by as much as three to fivefold (Hirsch et al. 2006). This has increased atmospheric nitrogen deposition and greatly promoted nitrogen input into temperate forests worldwide (Galloway et al. 2004). Long-term nitrogen deposition has resulted in the phenomenon called "nitrogen saturation" in temperate forest systems. In this situation, the availability of inorganic nitrogen exceeds the total demand from plants and microorganisms (Aber et al. 1989). A conceptual model of Aber et al. (1989) derived from previous papers postulates temporal patterns of a series of changes in forest ecosystems with nitrogen load, where the forest situation is progressively changed from an initial nitrogen limitation to an eventual nitrogen saturation. The nitrogen saturation is illustrated to activate soil nitrification to increase not only $\mathrm{NO}_{3}{ }^{-}$leaching but also $\mathrm{N}_{2} \mathrm{O}$ emissions from forest ecosystems. Thus, nitrogen saturation could be a principal factor contributing to $\mathrm{N}_{2} \mathrm{O}$ emissions from temperate forests. However, in current nitrogen saturation models that simulate nitrogen cycling affected by nitrogen deposition, $\mathrm{N}_{2} \mathrm{O}$ emissions have not been included due to the lack of appropriate basal data (Aber et al. 1989; Lovett and Goodale 2011).

Studies have been conducted over the last three decades to understand the fundamental implications of nitrogen saturation in forest ecosystems. The most widely adopted approach is the short- or long-term observation of forests after $\mathrm{N}$ addition (e.g., Venterea et al. 2004; Zhang et al. 2012). A recent compilation of 313 observations from $\mathrm{N}$ addition experiments indicated that $\mathrm{N}_{2} \mathrm{O}$ emissions increased by an average of $216 \%$ relative to the control (Liu and Greaver 2009) although no significant linear correlation was noted between $\mathrm{N}$ addition and $\mathrm{N}_{2} \mathrm{O}$ emissions. In other studies of forest ecosystems, the risk of $\mathrm{N}_{2} \mathrm{O}$ flux increase under elevated nitrogen deposition has been underscored (e.g., Eickenscheidt et al. 2011). However, $\mathrm{N}$ addition did not always stimulate $\mathrm{N}_{2} \mathrm{O}$ flux: simulated nitrogen deposition decreased (e.g., Skiba et al. 1999) or did not change (e.g., Borken and Beese 2005) soil $\mathrm{N}_{2} \mathrm{O}$ emissions. As a reason why $\mathrm{N}$ addition did not promote $\mathrm{N}_{2} \mathrm{O}$ emissions from $\mathrm{N}$-poor temperate forest soils, Cheng et al. (2016) have suggested that soil $\mathrm{N}_{2} \mathrm{O}$ flux is under strong control by the competitive interactions for soil available $\mathrm{N}$ between plants and nitrifiers. Although simulated $\mathrm{N}$ addition approaches have been commonly employed, applicable quantitative data on the impact of nitrogen saturation on $\mathrm{N}_{2} \mathrm{O}$ emissions from forest ecosystems have been limited.

A comparative field survey to study the in situ situation of forest ecosystems across a gradient of 
nitrogen availability could be an alternative effective approach. Perakis and Sinkhorn (2011) indicated that nitrate leaching has a positive relationship with net nitrification and soil $\mathrm{N}$ in forests having a wide soil $\mathrm{N}$ gradient in the United States. One group of Japanese forest researchers measured $\mathrm{N}_{2} \mathrm{O}$ emissions in 26 forests for 2 years and found a positive correlation between $\mathrm{N}_{2} \mathrm{O}$ flux and nitrification rate (Morishita et al. 2011). However, there have been few systematic field studies of the effects of nitrogen saturation on $\mathrm{N}_{2} \mathrm{O}$ emissions in natural temperate forest ecosystems.

Theoretically, nitrogen availability should be an important factor regulating $\mathrm{N}_{2} \mathrm{O}$ emissions because temperate forest ecosystems are nitrogen-limited in general (Vitousek and Howarth 1991; LeBauer and Treseder 2008). Nitrification, a key process for $\mathrm{N}_{2} \mathrm{O}$ production, is the weakest competitor for $\mathrm{NH}_{4}{ }^{+}$(Jones and Richards 1977) and it has been reported that forest soils may have no detectable nitrification activity (Vitousek et al. 1982; De Boer et al. 1988; Killham 1990). On the other hand, $\mathrm{N}_{2} \mathrm{O}$ emission is expected to only start in terrestrial ecosystems when nitrifiers can acquire $\mathrm{NH}_{4}{ }^{+}$that will be increased with elevated nitrogen availability.

In this study, $\mathrm{N}_{2} \mathrm{O}$ emissions were monitored for 3 years in a small watershed of a deciduous forest located in the suburbs of Tokyo, in which nitrogen saturation has been indicated from the elevated $\mathrm{NO}_{3}{ }^{-}$ concentrations in deep soils (Yoh et al. 2001). In addition, a comparative field survey was carried out in nine temperate forest sites in central Japan having different stream water $\mathrm{NO}_{3}{ }^{-}$concentrations and different nitrogen deposition rates. We tested the hypothesis that $\mathrm{N}_{2} \mathrm{O}$ emissions would increase with nitrogen availability associated with the progress of nitrogen saturation, as indicated by a positive correlation between $\mathrm{N}_{2} \mathrm{O}$ flux and nitrate leaching.

\section{Materials and methods}

Research site

Intensively studied forest site

Monthly field research was conducted in an N-saturated forest site (Tama) located in the suburbs of Tokyo, Japan $\left(35^{\circ} 38^{\prime} \mathrm{N}, 139^{\circ} 22^{\prime} \mathrm{E}\right)$. Nitrogen saturation status was indicated by elevated nitrate concentrations in deep soil and stream water (Yoh et al. 2001). Mean annual temperature and annual precipitation were $14.4{ }^{\circ} \mathrm{C}$ and $1600 \mathrm{~mm}$, respectively. Open bulk nitrogen deposition was $19.7 \mathrm{kgN}$ $\mathrm{ha}^{-1}$ year $^{-1}$ and forest throughfall was $19.1 \mathrm{kgN} \mathrm{ha}^{-1}$ year $^{-1}$ in oak forest (Kimura et al. 2009). Tama is a terrace underlain by interglacial marine deposits that emerged from the sea 300,000 to 500,000 years ago (Baba et al. 1995). Aeolian volcanic ashes from Mt. Hakone and Mt. Fuji deposited on Tama, resulting in a thick andosol layer. Vegetation in the studied area consists of oak (Quercus serrata) with understory bamboo grass. Forest floor type is mull.

A small watershed was used for flux measurement as described below to consider heterogeneity of microbial processes due to topographical position. The watershed contains a gentle slope and a steep slope with elevations ranging from 145 to $175 \mathrm{~m}$ (Fig. 1). Near the turning point between the steep slope and the gentle slope, a small discharge sometimes occurs in summer owing to elevated groundwater levels (Fig. 1).

\section{Gradient sites}

In order to investigate the effect of nitrogen availability on $\mathrm{N}_{2} \mathrm{O}$ emissions, we selected eight temperate forest sites in rural or mountainous regions having a range of nitrogen statuses as gradient sites (Table 1, Fig. 2). Stream $\mathrm{NO}_{3}{ }^{-}$concentrations varied by nearly 12-fold, which means that the selected forest sites have a large range of nitrogen statuses. Deciduous broad-leaved trees were predominant in those sites, similar to Tama, as described above.

All of the field studies at the gradient sites were conducted once in summer as a snapshot study, when high emissions were expected due to elevated temperatures and humid conditions. Detailed field properties are described in Table 1. Kusaki site was reported to be N-saturated (Ohrui and Mitchell 1997).

Field survey and sampling

\section{Measurement of $\mathrm{N}_{2} \mathrm{O}$ flux}

$\mathrm{N}_{2} \mathrm{O}$ flux was measured by means of a closed chamber method using a rectangular plastic chamber $(25 \mathrm{~cm} \times$ $15 \mathrm{~cm}$ and $20 \mathrm{~cm}$ in height). Twelve permanent chamber bases were embedded in soil to 


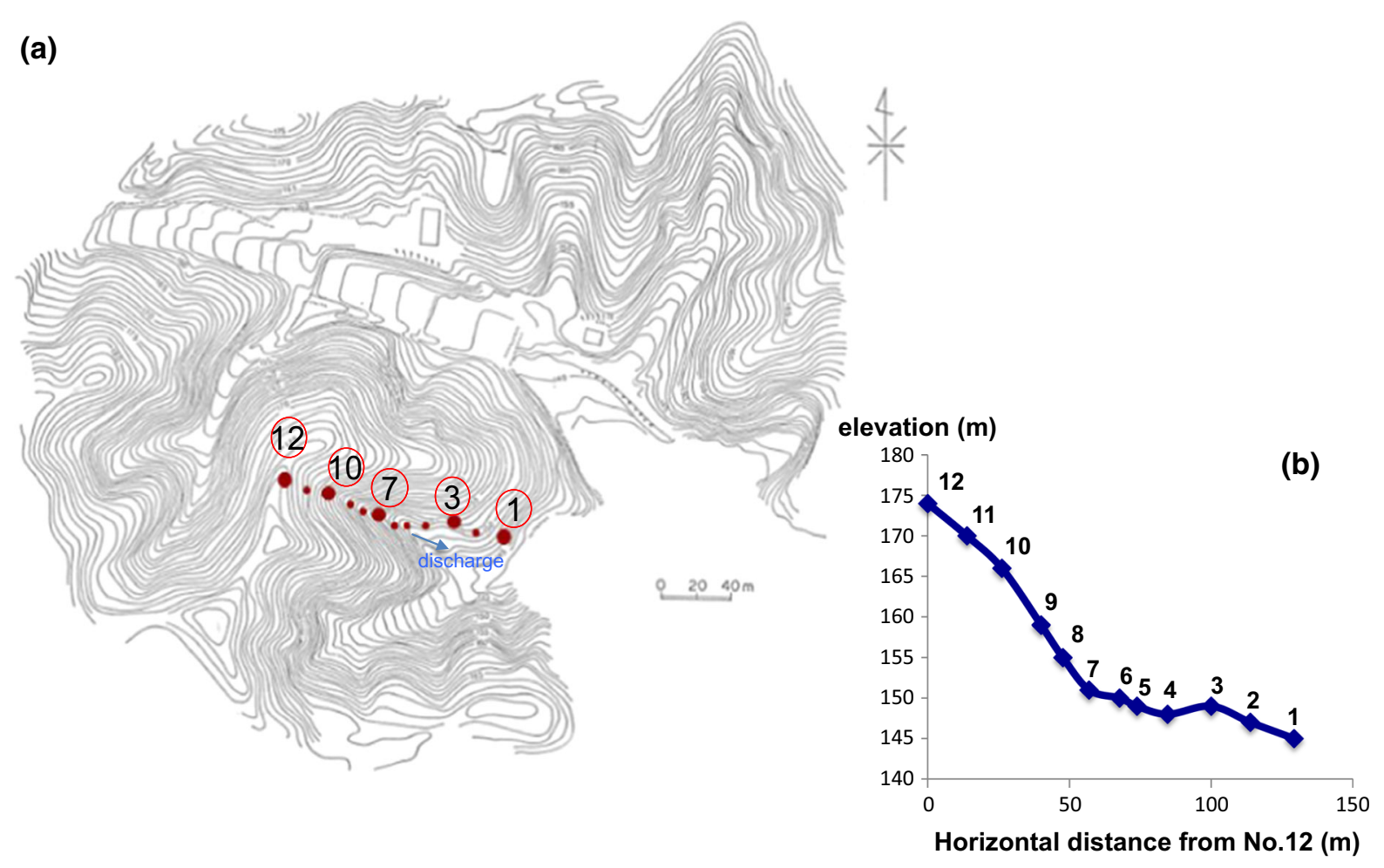

Fig. 1 Topographic map (a) and cross-section drawing (b) of twelve fixed plots set along a slope for $\mathrm{N}_{2} \mathrm{O}$ flux measurement in Tama

approximately $5 \mathrm{~cm}$ depth to reduce the effects of soil disturbance resulting from the chamber embedment in March 2012. Fifteen milliliters of gas sample was collected 0,15 , and $30 \mathrm{~min}$ after closing the plastic chamber and transferred into a $12-\mathrm{mL}$ pre-evacuated vial.

It has been suggested that slope position is important for the determination of spatial variability of $\mathrm{N}_{2} \mathrm{O}$ emissions (McSwiney et al. 2001; Osaka et al. 2006), although knowledge of spatial topographic factors is limited (Nishina et al. 2009; Christiansen et al. 2012). Therefore, twelve plots were set along a slope covering the whole watershed (Fig. 1) to determine the influence of slope position and understand the $\mathrm{N}_{2} \mathrm{O}$ flux in the entire watershed. Measurement was conducted monthly from May 2012 to May 2015.

We selected eight gradient sites with various watershed sizes, slopes and directions that were all covered with broad-leaved forests (mostly oak trees), but were expected to have different nitrogen status. Six same chambers as above were distributed along the slope of the watershed to cover spatial variation.
The chambers were embedded in soil to approximately $5 \mathrm{~cm}$ depth $0.5-1 \mathrm{~h}$ before measurement.

\section{Preparation of samples for related parameters}

Surface soil $(5 \mathrm{~cm})$ temperature was measured near the chamber while gas was sampled. Three soil samples were collected from surface mineral soil $(0-10 \mathrm{~cm})$ at respective sites near the chambers for chemical analyses. One soil sample was prepared from 3-5 sampling points. Stream water was also collected from respective watersheds to measure $\mathrm{NO}_{3}{ }^{-}$concentration. All the watersheds had no inflows from anthropogenic activities such as human habitation and agricultural practices. All samples were kept cool during the transport. In the laboratory, soils were sieved immediately by passing through $2 \mathrm{~mm}$ sieves for late analyses.

In situ soil incubation experiment

Net nitrification rate was determined in situ for surface soil $(0-10 \mathrm{~cm})$ in Tama by a covered cylinder method 


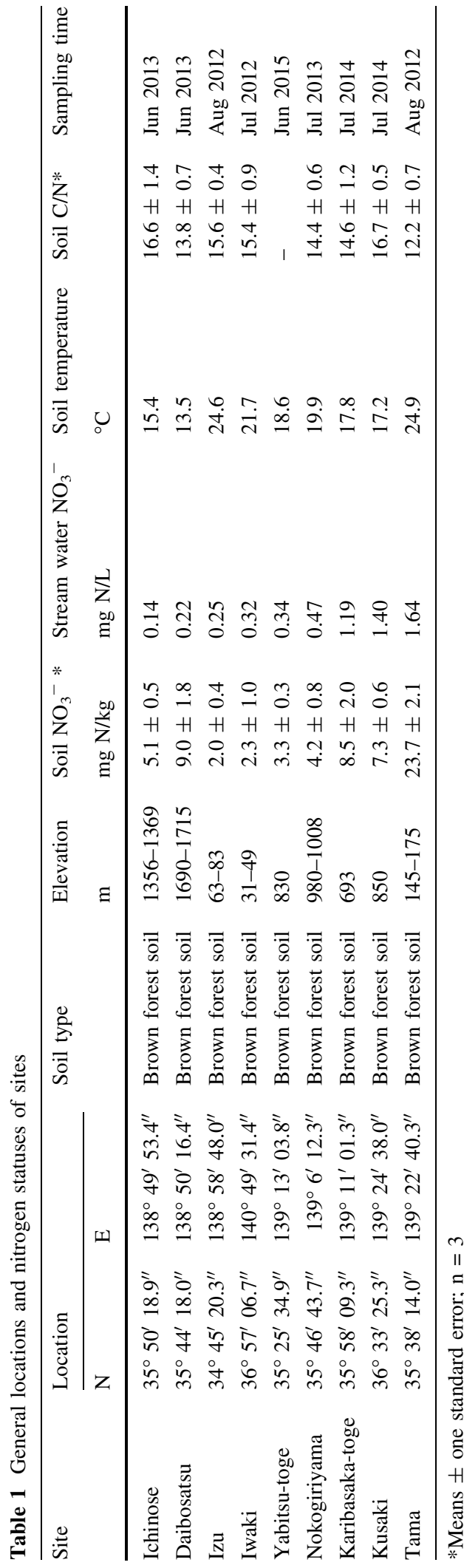

(Hatch et al. 1998) in July and October 2012, June 2014, and February 2015. Measurements were conducted for plots 1, 3, 7, 10, and 12 (Fig. 1a). In situ soil incubation experiments were conducted near the chamber (within $1 \mathrm{~m}$ ) to compare with the $\mathrm{N}_{2} \mathrm{O}$ fluxes.

Six PVC cylinders (inserted depth: $10 \mathrm{~cm}$, inner diameter: $5.5 \mathrm{~cm}$ ) per plot were embedded in the soil perpendicularly. Three of the six cylinders were immediately excavated and transported to the laboratory. The soil samples were kept cold during transport. In the laboratory, $0-10 \mathrm{~cm}$ of surface mineral soil from each plot was mixed. Half of the soil was used for water content measurement and the other half was used for water extraction for chemical analysis of soil mineral $\mathrm{N}$ ( $\mathrm{t}_{0}$ samples). The remaining three cylinders were incubated in situ. After one month, the cylinders were excavated and the soil samples from the cylinders ( $t_{1}$ samples) were subjected to the same procedure as that for the $\mathrm{t}_{0}$ samples.

Net nitrification rate was calculated as follows:

Net nitrification rate $\left(\mathrm{mg} \mathrm{N} / \mathrm{m}^{2} /\right.$ day $)$

$$
\begin{aligned}
= & \left(\left[\mathrm{NO}_{3}^{-}\right]_{\text {afterincubation }}-\left[\mathrm{NO}_{3}^{-}\right]_{\text {beforeincubation }}\right) \times \rho \\
& \times h / t
\end{aligned}
$$

$\left[\mathrm{NO}_{3}{ }^{-}\right]: \mathrm{NO}_{3}{ }^{-}$concentration (mg N/g soil); $\rho$ : soil density $\left(\mathrm{g} \mathrm{soil} / \mathrm{m}^{3}\right)$; h: depth of soil sampled $(0.1 \mathrm{~m}$; assumed); t: incubation time (30 days).

Analyses

\section{Analysis of $\mathrm{N}_{2} \mathrm{O}$ concentration and calculation}

$\mathrm{N}_{2} \mathrm{O}$ concentrations in the vials were determined with a gas chromatograph (GC) equipped with an electron capture detector (ECD). The ECD-GC (Shimadzu GC14B, Kyoto, Japan) was equipped with a $3 \mathrm{~m}$ Porapak Q column (80-100 mesh). Oven, injection, and detection temperatures were $60{ }^{\circ} \mathrm{C}, 80^{\circ} \mathrm{C}$, and $340{ }^{\circ} \mathrm{C}$, respectively. Pure nitrogen $(>99.99995 \%$ ) was used as carrier gas at the flow rate of $20 \mathrm{~mL} \mathrm{~min}^{-1}$.

$\mathrm{N}_{2} \mathrm{O}$ flux was determined by calculating the linear regression of the change in $\mathrm{N}_{2} \mathrm{O}$ concentration in the chamber with time and expressed as $\mu \mathrm{g} \mathrm{N} \mathrm{m}^{-2} \mathrm{~h}^{-1}$. Linear regression analyses of the measurement series with an $\mathrm{R}^{2}$ value higher than 0.8 were used for flux calculation. 


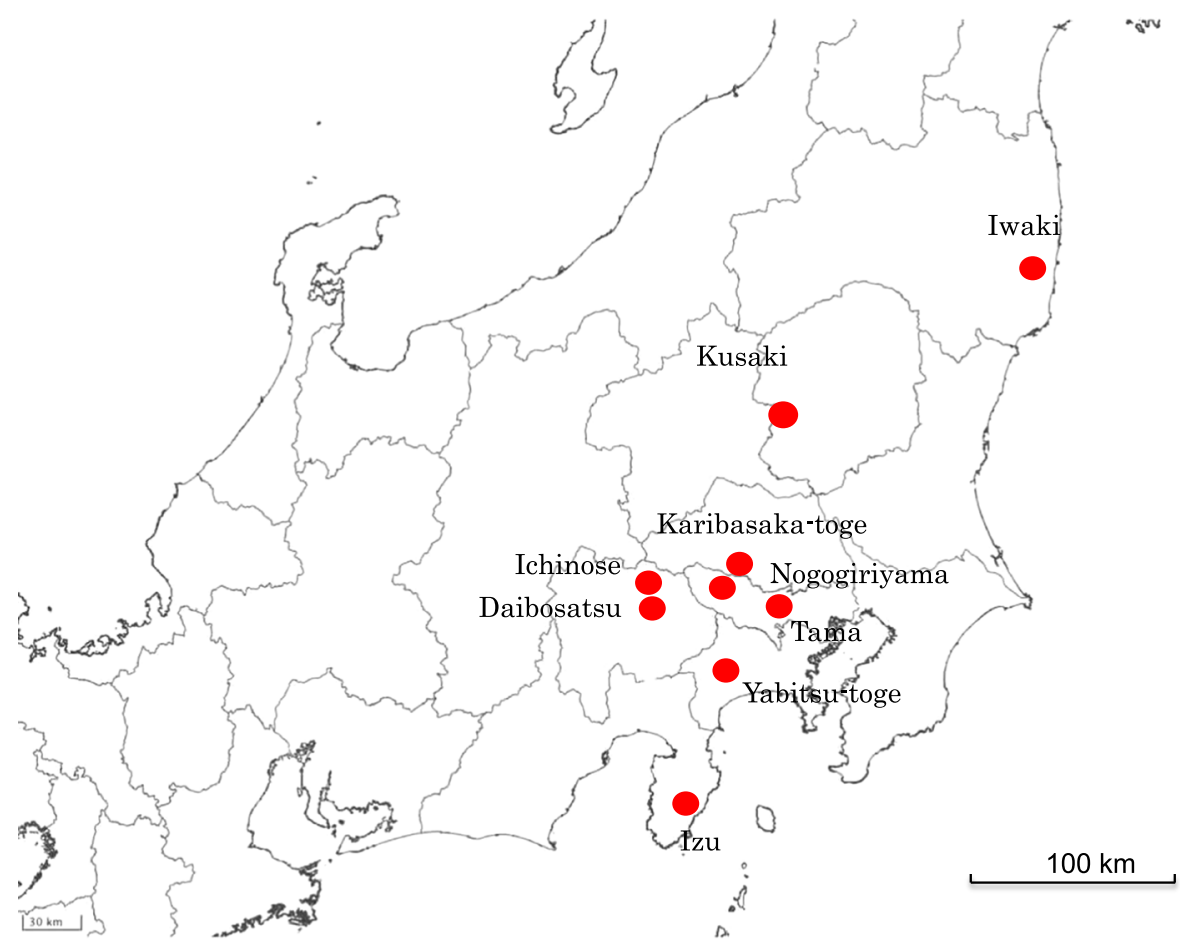

Fig. 2 Locations of intensively studied forest site (Tama) and eight gradient sites

$\mathrm{N}_{2} \mathrm{O}$ flux at each plot was calculated using the following equation:

$\mathrm{N}_{2} \mathrm{O}$ flux $\left(\mu \mathrm{gN} \mathrm{m}{ }^{-2} \mathrm{~h}^{-1}\right)=\rho \times \mathrm{V} / \mathrm{A} \times \mathrm{dc} / \mathrm{dt} \times \alpha$

$\rho$ : gas density of $\mathrm{N}_{2} \mathrm{O}$ at STP $\left(1.978 \times 10^{9} \mu \mathrm{g} \mathrm{m}^{-3}\right)$; $\mathrm{V}$ : volume of chamber $\left(\mathrm{m}^{3}\right)$; A: cross-sectional area of chamber $\left(\mathrm{m}^{2}\right)$; dc/dt: rate of change in gas concentration (c) inside the chamber per unit time $(\mathrm{t})\left(\mathrm{m}^{3}\right.$ $\mathrm{m}^{-3} \mathrm{~h}^{-1}$ ); $\alpha$ : conversion factor for transforming $\mathrm{N}_{2} \mathrm{O}$ into $\mathrm{N}(28 / 44)$.

Because it was expected that $\mathrm{N}_{2} \mathrm{O}$ flux would be different among plots due to different soil conditions, $\mathrm{N}_{2} \mathrm{O}$ flux was quantified for each of the twelve plots. Furthermore, monthly $\mathrm{N}_{2} \mathrm{O}$ flux from the entire watershed studied was estimated by summing them up.

Monthly $\mathrm{N}_{2} \mathrm{O}$ flux $\left(\mathrm{g} \mathrm{N} \mathrm{ha}^{-1}\right.$ month $\left.^{-1}\right)$

$$
=\sum_{1-12}\left[\mathrm{~N}_{2} \mathrm{O} \text { flux } \times \mathrm{A} \times 24 \times 30 \times 10^{4} / 10^{6}\right] / \mathrm{S}
$$

A: area represented by each plot $\left(\mathrm{m}^{2}\right)$.

We assume that all of the plots have the same area; i.e., $\mathrm{A}=\mathrm{S} \times 1 / 12$.

S: total watershed area (ha).
Annual $\mathrm{N}_{2} \mathrm{O}$ flux was calculated by summing up monthly $\mathrm{N}_{2} \mathrm{O}$ fluxes.

\section{Nitrate concentration}

Soil water extract was collected after shaking $5 \mathrm{~g}$ of subsamples of sieved soil with $50 \mathrm{~mL}$ of pure water for $60 \mathrm{~min}$ and centrifuging for $10 \mathrm{~min}$. The supernatant was filtered using glass filters $(\mathrm{GF} / \mathrm{F}$; Whatman Int. Ltd.) and stored at $-20{ }^{\circ} \mathrm{C}$ until analysis. Nitrate was analyzed by ion chromatography (Dionex DX120). Nitrite was negligible throughout.

\section{C/N ratio}

The determination of total nitrogen and total carbon in mineral soils of $0-10 \mathrm{~cm}$ depth was carried out by dry combustion using a CN coder (Yanaco MT-700). Soil samples dried at $60{ }^{\circ} \mathrm{C}$ were comminuted and approximately $100 \mathrm{mg}$ of the thoroughly mixed sample was used for measurement. 


\section{Physical properties}

Bulk density of soil samples was determined by oven drying at $105{ }^{\circ} \mathrm{C}$. Soil temperature at $5 \mathrm{~cm}$ depth was measured with a digital thermometer (YOKOGAWA MODEL 2455). $\mathrm{pH}$ of a soil-water mixture (1:2.5 (v/ v)) was determined using a glass electrode. Waterfilled pore space (WFPS) was calculated from the following formula:

$$
\begin{aligned}
\operatorname{WFPS}(\%)= & \text { Soil water content }(\%) \times \rho_{\mathrm{V}} /(1 \\
& \left.-\rho_{\mathrm{v}} / 2.65\right)
\end{aligned}
$$

$\rho_{\mathrm{v}}$ : soil bulk density $\left(\mathrm{g} \mathrm{cm}^{-3}\right) ; 2.65$ : particle density of soil (assumed).

\section{Results}

Soil moisture

WFPS values varied according to slope position (Fig. 3). Plot 1 had low values of $30-45 \%$, whereas plot 7 showed significantly high values of 55-68\%. Although plot 1 located at the end of a gentle slope had the highest soil moisture content, its low soil density resulted in the lowest calculated values of WFPS. Most of the WFPS values were $<60 \%$, but WFPS values in plots 7 and 10 in July 2012 were $>60 \%$, suggesting that anaerobic processes could be operative. Generally, WFPS tended to be high in summer, the season that had more rainfall.
$\mathrm{N}_{2} \mathrm{O}$ flux

Considerable spatial variation in annual $\mathrm{N}_{2} \mathrm{O}$ flux was found in the twelve plots set along a slope in Tama (Fig. 4), ranging from $0.4 \mathrm{~kg} \mathrm{~N} \mathrm{ha}^{-1}$ year $^{-1}$ (plot 1) to $1.9 \mathrm{~kg} \mathrm{~N} \mathrm{ha}^{-1}$ year $^{-1}$ (plot 8). The highest fluxes were observed at the inflection point between the gentle slope and the steep slope (plots 6-8), where high WFPS values were observed (Fig. 3). The fluxes were relatively low at both ends of the slope where low WFPS values were observed (Fig. 3).

The $\mathrm{N}_{2} \mathrm{O}$ fluxes in the entire watershed measured monthly in Tama are shown in Fig. 5. The $\mathrm{N}_{2} \mathrm{O}$ fluxes showed typical seasonal variations, which were closely related to soil temperature at $5 \mathrm{~cm}$ depth (data not shown): high $\mathrm{N}_{2} \mathrm{O}$ emissions in summer and minimum emissions, almost close to zero, in winter (Fig. 5).

In this intensively studied $\mathrm{N}$-saturated forest, the average annual $\mathrm{N}_{2} \mathrm{O}$ emissions from the entire watershed were estimated to be $0.88 \mathrm{~kg} \mathrm{~N}^{-1}$ year $^{-1}$.

$\mathrm{N}_{2} \mathrm{O}$ fluxes at the gradient sites and the intensively studied forest site (Tama), which were all measured in summer, are compared in Fig. 6. $\mathrm{N}_{2} \mathrm{O}$ fluxes varied by approximately 34 -fold across the nine forest sites, ranging from $0.13 \mathrm{~g} \mathrm{~N} \mathrm{ha}^{-1} \mathrm{day}^{-1}$ to $4.38 \mathrm{~g} \mathrm{~N}^{-1}$ day $^{-1}$. Markedly high $\mathrm{N}_{2} \mathrm{O}$ flux was observed in Tama (Fig. 6).

Soil $\mathrm{NO}_{3}{ }^{-}$concentration in Tama was also several times higher than those in the gradient sites. Stream water $\mathrm{NO}_{3}{ }^{-}$concentration varied by approximately 12-fold across the nine forest sites, ranging from 0.14

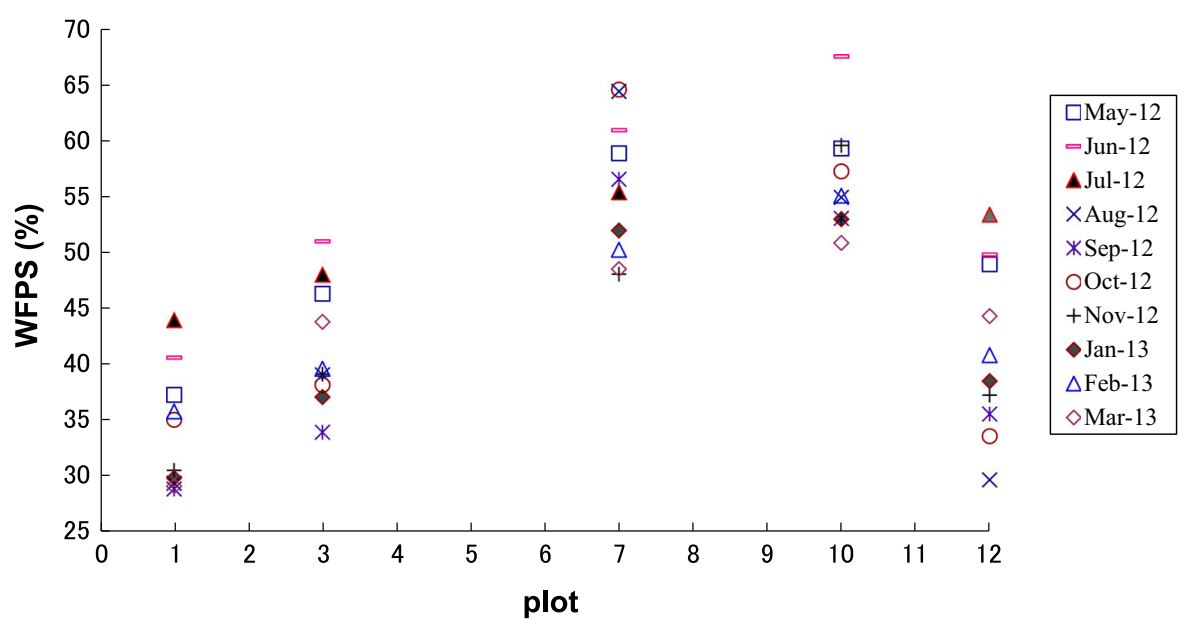

Fig. 3 Spatial and temporal variations of water-filled pore spaces during the study period in Tama 
Fig. 4 Spatial variations of $\mathrm{N}_{2} \mathrm{O}$ fluxes in Tama. Points and error bars are the averages and the standard deviations of annual $\mathrm{N}_{2} \mathrm{O}$ fluxes for 3 years
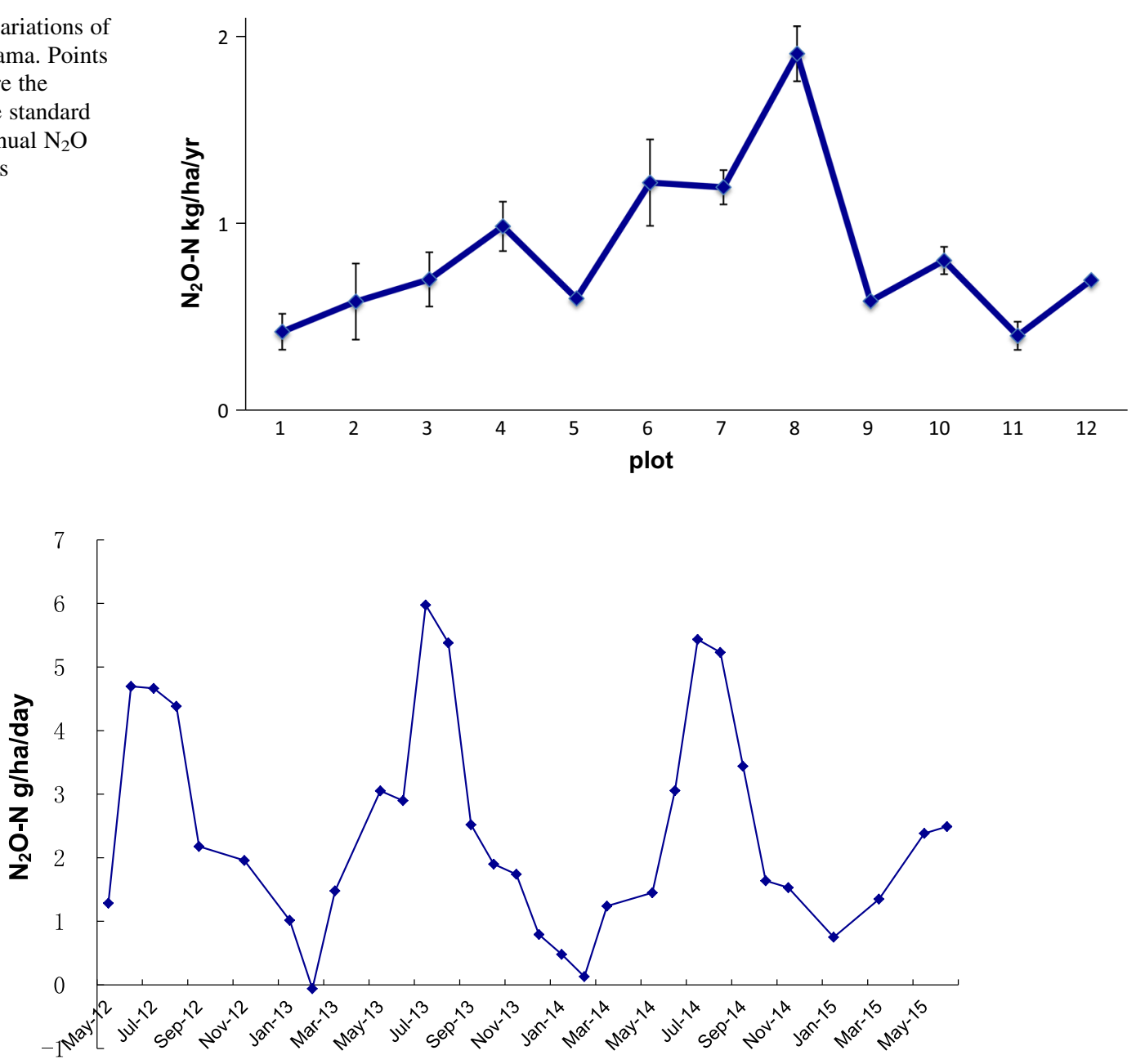

Fig. 5 Seasonal variations of $\mathrm{N}_{2} \mathrm{O}$ fluxes in Tama. The $\mathrm{N}_{2} \mathrm{O}$ flux was measured for the entire watershed (See text for details)

to $1.64 \mathrm{mg} \mathrm{N} / \mathrm{L}$. Stream water $\mathrm{NO}_{3}{ }^{-}$concentration varied almost in parallel with $\mathrm{N}_{2} \mathrm{O}$ emissions; a high concentration was associated with high $\mathrm{N}_{2} \mathrm{O}$ emissions and vice versa. Soil $\mathrm{C} / \mathrm{N}$ ratio (Table 1 ) showed no significant correlation with stream water $\mathrm{NO}_{3}{ }^{-}$concentration or $\mathrm{N}_{2} \mathrm{O}$ emissions among the eight forest sites studied here, although previous studies have suggested that soil $\mathrm{C} / \mathrm{N}$ ratio is a contributing factor to nitrate leaching (Gundersen et al. 1998) and $\mathrm{N}_{2} \mathrm{O}$ emissions (Klemedtsson et al. 2005; Pilegaard et al. 2006; Gundersen et al. 2012). The lack of correlation may be due to the relatively low soil $\mathrm{C} / \mathrm{N}$ ratios in the present study; clear correlations were just observed for large-spans of soil $\mathrm{C} / \mathrm{N}$ ratios in the previous studies.

\section{Nitrification}

The net nitrification rate in Tama showed a wide variation ranging from -3 to $69.8 \mathrm{mg} \mathrm{N} / \mathrm{m}^{2} /$ day. For the same plots, the net nitrification rate varied generally with soil temperature, being high in summer and low in winter (Table 2). Spatially, there was a consistent pattern in the net nitrification rate; it was generally higher at lower positions (plots 1 and 3) than upper positions (plots 10 and 12) (Table 2). Enhanced aeration due to relatively low soil density as well as low WFPS value could result in the high net nitrification rates in the gentle-slope plots near the bottom. For plot 7, which is located at the inflection point between the gentle slope and the steep slope, the net nitrification rates were invariably low and there were 


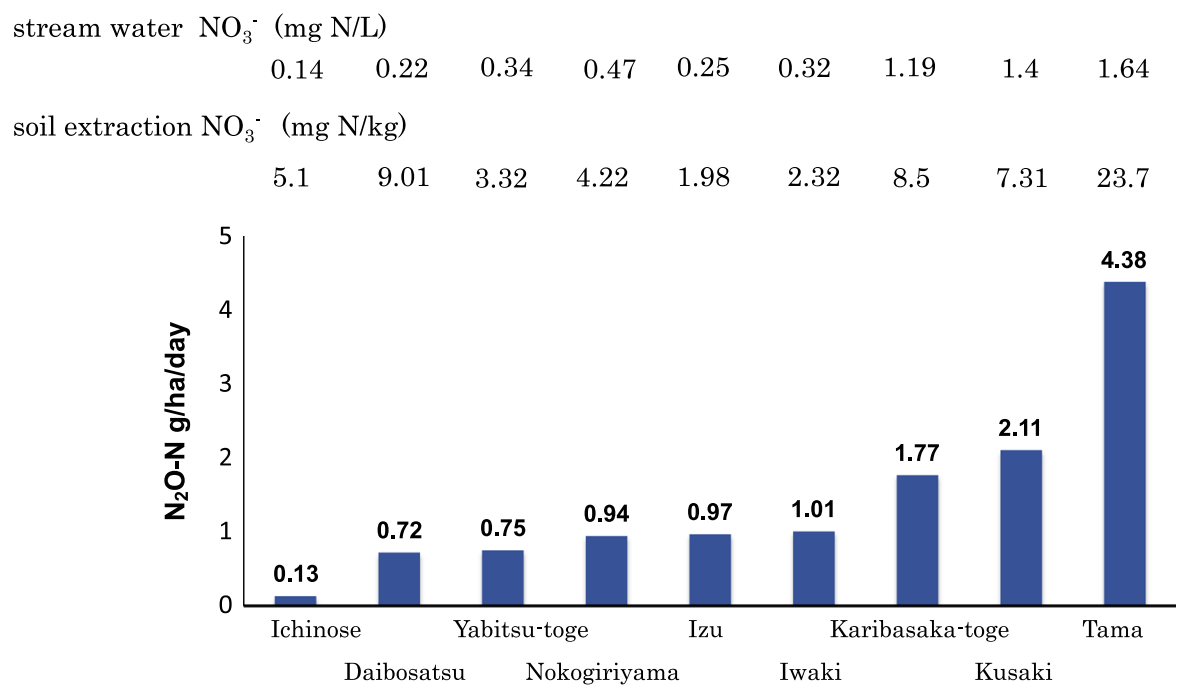

Fig. $6 \mathrm{~N}_{2} \mathrm{O}$ fluxes in forest sites having different nitrate concentrations in stream water and soil. Data were collected at the sampling times shown in Table 1

Table 2 Net nitrification rates and related variables in the incubation experiment in Tama

\begin{tabular}{|c|c|c|c|c|}
\hline Incubation period & Plot & Soil temperature ${ }^{\circ} \mathrm{C}$ & WFPS $\%$ & Net nitrification rate $\mathrm{mg} \mathrm{N} / \mathrm{m}^{2} /$ day \\
\hline \multirow[t]{5}{*}{ Jul-2012 } & 1 & 22.4 & 44 & 55.3 \\
\hline & 3 & 22.8 & 48 & 38.6 \\
\hline & 7 & 22.8 & 61 & -3 \\
\hline & 10 & 23.5 & 70 & 33.7 \\
\hline & 12 & 22.8 & 53 & 41.4 \\
\hline \multirow[t]{5}{*}{ Oct-2012 } & 1 & 16.8 & 30 & 69.8 \\
\hline & 3 & 17.4 & 39 & 29.7 \\
\hline & 7 & 16.9 & 48 & 3.9 \\
\hline & 10 & 16.9 & 58 & 7.4 \\
\hline & 12 & 17.1 & 37 & 21 \\
\hline \multirow[t]{5}{*}{ Jun-2014 } & 1 & 19.5 & 34 & 20.9 \\
\hline & 3 & 19.7 & 39 & 15.5 \\
\hline & 7 & 19.5 & 66 & -0.7 \\
\hline & 10 & 19.9 & 65 & 10 \\
\hline & 12 & 19.7 & 38 & 3 \\
\hline \multirow[t]{5}{*}{ Feb-2015 } & 1 & 4.5 & 40 & 9.2 \\
\hline & 3 & 4.7 & 41 & 6.9 \\
\hline & 7 & 4.7 & 60 & 0.9 \\
\hline & 10 & 4.6 & 72 & 6.1 \\
\hline & 12 & 4.8 & 41 & 2.3 \\
\hline
\end{tabular}

WFPS, soil temperature, and $\mathrm{N}_{2} \mathrm{O}$ fluxes were surveyed at the same time

two negative values, both of which were measured in summer (July 2012 and June 2014). These exceptionally low fluxes would be due to the excessive moisture (higher than 60\%) in soil arising from abundant rainfall in summer and groundwater seepage at this location (Fig. 3). The high WFPS condition should 
Fig. 7 Relationships between net nitrification rate and $\mathrm{N}_{2} \mathrm{O}$ flux. Data were collected from field incubation experiments in Tama and are shown in Table 2

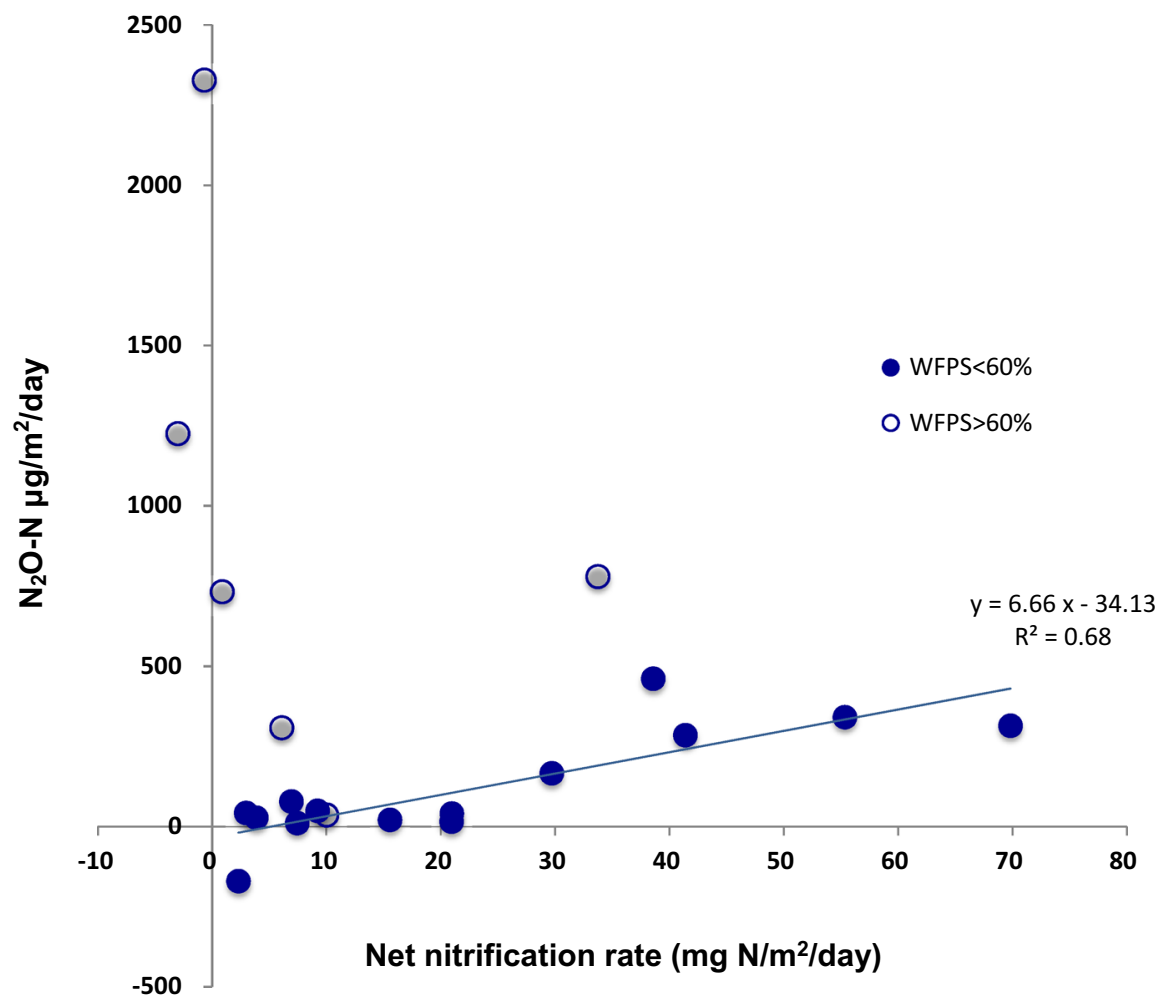

create an anaerobic condition in the soil to suppress nitrification and $\mathrm{NO}_{3}{ }^{-}$production, and at the same time promote denitrification resulting in consumption of available $\mathrm{NO}_{3}{ }^{-}$.

The relationship between $\mathrm{N}_{2} \mathrm{O}$ flux and net nitrification rate in Tama is shown in Fig. 7. A clear positive correlation was found between $\mathrm{N}_{2} \mathrm{O}$ flux and net nitrification rate for WFPS $<60 \%$ (Fig. 7), indicating that nitrification is the major process responsible for $\mathrm{N}_{2} \mathrm{O}$ production under well-aerated conditions. The slope of the regression line, which corresponds to the ratio of $\mathrm{N}_{2} \mathrm{O}$ production during nitrification, is equivalent to $0.66 \%$. For WFPS $>60 \%$ (data from plots around the bottom of a steep slope (plots 7 and 10) in the rainy season (July 2012 and June 2014)), in contrast, no correlation was found between $\mathrm{N}_{2} \mathrm{O}$ flux and net nitrification rate. The scattered data for WFPS $>60 \%$ in Fig. 7 might be due to nitrate consumption and elevated $\mathrm{N}_{2} \mathrm{O}$ emissions affected by denitrification, which occurred under exceedingly humid conditions at a particular period (summer) and at particular locations with groundwater seepage.

\section{Discussion}

The average annual $\mathrm{N}_{2} \mathrm{O}$ emissions from the $\mathrm{N}$-saturated forest (Tama) were estimated to be $0.88 \mathrm{~kg} \mathrm{~N} \mathrm{ha}^{-1}$ year $^{-1}$; instantaneous flux rate ranged from -0.03 to $90 \mu \mathrm{g} \mathrm{N} \mathrm{m}^{-2} \mathrm{~h}^{-1}$. The fluxes observed in the present study are higher than those reported for other forest ecosystems in Japan (e.g., $0.106 \mathrm{~kg} \mathrm{~N} \mathrm{ha}^{-1}$ year $^{-1}$ (Morishita et al. 2011), $0.66 \pm 0.03 \mu \mathrm{g} \mathrm{N} \mathrm{m}^{-2} \mathrm{~h}^{-1}$ (Inatomi et al. 2010), and $0.17-12.5 \mu \mathrm{g} \mathrm{N} \mathrm{m}^{-2} \mathrm{~h}^{-1}$ at 26 sites (Morishita et al. 2007)) and in North America ( -0.03 to $0.06 \mathrm{~kg} \mathrm{~N} \mathrm{ha}^{-1}$ year $^{-1}$ (Castro et al. 1992) and 0.01-0.02 kg N ha ${ }^{-1}$ year $^{-1}$ (Bowden et al. 1990)). In Europe, similar high $\mathrm{N}_{2} \mathrm{O}$ fluxes, e.g., $0.67-0.92 \mathrm{~kg} \mathrm{~N}^{-1}$ year $^{-1}$ (Schmidt et al. 1988) and $0.55-0.62 \mathrm{~kg} \mathrm{~N} \mathrm{ha}^{-1}$ year $^{-1}$ (Kesik et al. 2005), were reported. Still higher $\mathrm{N}_{2} \mathrm{O}$ fluxes, e.g., 1.15-2.29 kg N ha ${ }^{-1}$ year $^{-1}$ (Pitcairn et al. 2002) and $2.6 \mathrm{~kg} \mathrm{~N} \mathrm{ha}^{-1}$ year $^{-1}$ (Eickenscheidt et al. 2011), were reported for $\mathrm{N}$-saturated forests having particularly low soil $\mathrm{pH}$ values. Thus, except for the high $\mathrm{N}_{2} \mathrm{O}$ emissions in some European forests, the 
Fig. 8 Relationship between $\mathrm{N}_{2} \mathrm{O}$ flux and stream water $\mathrm{NO}_{3}{ }^{-}$ concentration in all the sites. The regression line and the correlation coefficient are for all points excluding Tama

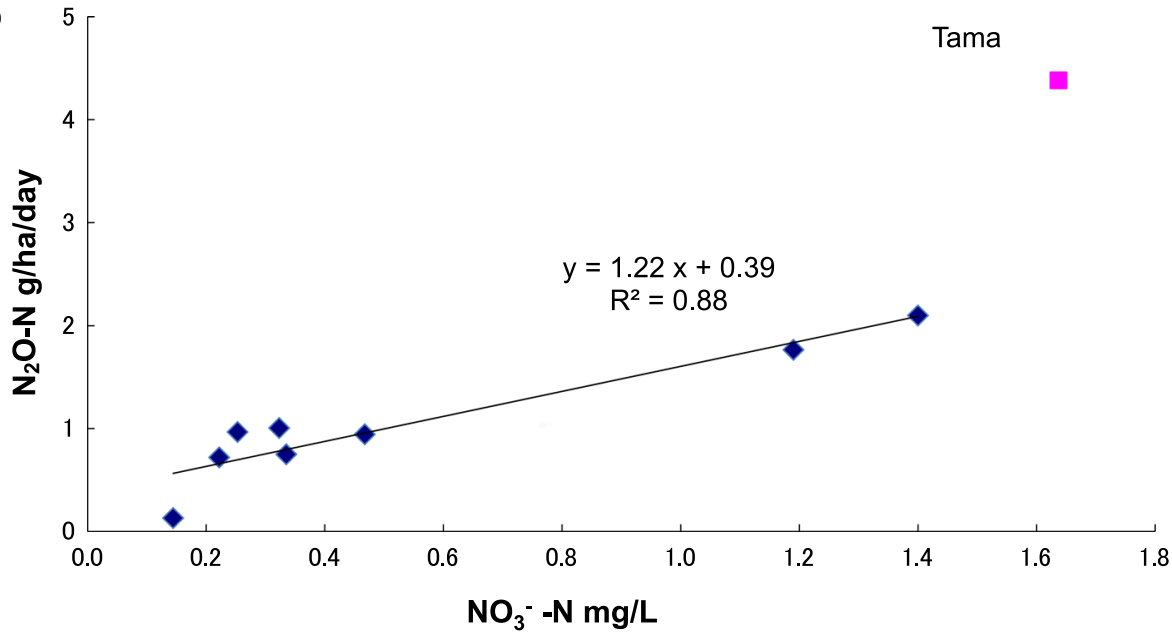

value estimated for Tama in this study is comparable to the highest level ever reported for temperate forests.

The $\mathrm{N}_{2} \mathrm{O}$ flux in Tama was higher than those in the gradient sites when values obtained in summer observations were compared. Soil $\mathrm{NO}_{3}{ }^{-}$concentration and stream water $\mathrm{NO}_{3}{ }^{-}$concentration were also the highest compared to the gradient sites. In the eight gradient sites, $\mathrm{N}_{2} \mathrm{O}$ fluxes were generally higher in the sites that had higher soil $\mathrm{NO}_{3}{ }^{-}$and stream water $\mathrm{NO}_{3}{ }^{-}$ concentrations (Fig. 6). The $\mathrm{N}_{2} \mathrm{O}$ flux varied across nine forest sites almost in proportional to the stream water $\mathrm{NO}_{3}{ }^{-}$concentration in the watershed that ranged from $0.14 \mathrm{mg} \mathrm{N} / \mathrm{L}$ to $1.64 \mathrm{mg} \mathrm{N} / \mathrm{L}$ (Fig. 8). In addition, a significant linear correlation between $\mathrm{N}_{2} \mathrm{O}$ flux and net nitrification rate was observed for well-aerated plots in Tama (Fig. 7). Thus, the results described above indicate that $\mathrm{N}_{2} \mathrm{O}$ emissions in the temperate forests studied here are proportional to the magnitude of nitrification. Morishita et al. (2011) also reported a positive correlation between $\mathrm{N}_{2} \mathrm{O}$ flux and nitrification rate in a 3-year experiment conducted in temperate forests (in the Kanto region) having the same climate as Tama. Several studies have pointed out that nitrification is the major process involved in $\mathrm{N}_{2} \mathrm{O}$ emissions from forest ecosystems (e.g., Castro et al. 1992; Venterea et al. 2004; Fang et al. 2009).

The slope of the regression line between $\mathrm{N}_{2} \mathrm{O}$ flux and net nitrification rate (except for humid condition) in Fig. 7, which corresponds to the ratio of $\mathrm{N}_{2} \mathrm{O}$ production during nitrification, was $0.66 \%$. This value is consistent with the ratio of $\mathrm{N}_{2} \mathrm{O}-\mathrm{N}$ emissions to nitrification of $0.05-0.15 \%$ reported by Hynes and
Knowles (1984) in a pure culture of Nitrosomonas europaea and the ratio of $\mathrm{N}_{2} \mathrm{O}-\mathrm{N}$ emissions to gross nitrification varying between $0.4 \%-2.1 \%$ in a ${ }^{15} \mathrm{~N}$ labeled incubation of soil in the laboratory reported by Venterea et al. (2004). Similar values of $0.39 \%$ (Maag and Vinther 1996) in a laboratory incubation experiment of forest soil and $0.23 \%$ (Morishita et al. 2011) in a field incubation experiment in a temperate forest have been also reported. Previous works on agricultural soil in the aerobic condition also showed the ratio of $\mathrm{N}_{2} \mathrm{O}-\mathrm{N}$ emissions to nitrification varying from 0.02 to $0.2 \%$ (mostly $<0.1 \%$ ) (e.g., Breitenbeck et al. 1980; Tortoso and Hutchinson 1990; Stevens et al. 1997; Mathieu et al. 2006).

The concurrent increase in $\mathrm{N}_{2} \mathrm{O}$ emissions and nitrate leaching is in accordance with the nitrogen saturation conceptual model proposed by Aber et al. (1989); both are negligible at 'stage 1' and increase simultaneously after 'stage 2 ' with the initiation of nitrification. Few such concurrent behaviors have been reported in previous studies of $\mathrm{N}_{2} \mathrm{O}$ emissions in temperate forests. The unique findings of clear relationships in the present study may be partly because microbial processes are much less limited by soil moisture due to the humid climate in central Japan, unlike forest research sites in Europe and the United States. Typical seasonal changes in $\mathrm{N}_{2} \mathrm{O}$ emissions observed in the present study, which have hardly been reported in previous studies of temperate forests, should also stem from this humid condition, which allows temperature to be the sole controlling factor. Relatively abundant rainfall and mountainous 
topographic features would also allow collection of stream waters. In addition, the contribution of denitrification in the watershed would be partial, if any, due to such conditions. It is likely that those conditions enabled us to clarify the relationships between $\mathrm{N}_{2} \mathrm{O}$ emissions and relevant parameters.

The setting of twelve plots along a slope covering the whole watershed revealed a unique feature of spatial variability and topographic factor in $\mathrm{N}_{2} \mathrm{O}$ emissions. The inflection point of the gentle slope and the steep slope (No. 6 and No. 7 in the intensively studied forest site) emits more than twice the amount of $\mathrm{N}_{2} \mathrm{O}$ in other plots. Such relatively high $\mathrm{N}_{2} \mathrm{O}$ emissions at the bottom of slope, which have also been pointed out by previous researchers (e.g., Osaka et al. 2006; Nishina et al. 2009), are related to the high WFPS value. The data points for Tama were located far from the regression line in Fig. 8. This could partly be attributed to this topographic effect. It is likely that under slightly elevated WFPS values, denitrification may contribute partly to $\mathrm{N}_{2} \mathrm{O}$ production because it has been shown that denitrification becomes increasingly important when WFPS exceeds $60 \%$ in agricultural and natural soils (e.g., Dobbie et al. 1999; Abbasi and Adams 2000; Skiba and Ball 2002; Bateman and Baggs 2005). It is also known that $\mathrm{N}_{2} \mathrm{O}$ yield during nitrification is elevated at low oxygen concentration (Goreau et al. 1980).

It is generally understood that nitrogen is limited in temperate forest ecosystems (Vitousek and Howarth 1991; LeBauer and Treseder 2008). It is common for forest soils to have no detectable nitrification activity (Vitousek et al. 1982; De Boer et al. 1988; Killham 1990). Aber et al. (1989) have also hypothesized no nitrification before starting chronic nitrogen deposition. The lack of nitrification activity is understandable when considering that nitrifiers are weak competitors for $\mathrm{NH}_{4}^{+}$(Jones and Richards 1977). However, nitrogen availability has been widely elevated due to chronic nitrogen deposition to initiate nitrification in forest ecosystems, a key process promoting $\mathrm{N}_{2} \mathrm{O}$ emissions. Nitrification inevitably produces $\mathrm{N}_{2} \mathrm{O}$ as a by-product and moreover enables denitrification by providing the substrate $\left(\mathrm{NO}_{3}{ }^{-}\right)$, which also contributes $\mathrm{N}_{2} \mathrm{O}$ emission. The correlations of $\mathrm{N}_{2} \mathrm{O}$ emissions to soil $\mathrm{NO}_{3}{ }^{-}$concentration (Fig. 6), stream water $\mathrm{NO}_{3}{ }^{-}$concentration (Figs. 6 and 8), and soil net nitrification rate (Fig. 7) strongly suggest that $\mathrm{N}_{2} \mathrm{O}$ emissions occur in parallel with the magnitude of nitrification. The large variation of $\mathrm{N}_{2} \mathrm{O}$ emissions in temperate forests, ranging from negligible to high emissions, was adequately accounted for by these variables associated with nitrification. Thus, it is reasonable to conclude that increased nitrogen availability due to anthropogenic nitrogen depositions will stimulate $\mathrm{N}_{2} \mathrm{O}$ emissions from temperate forests through enhanced nitrification. Percentage $\mathrm{N}_{2} \mathrm{O}$ emission is approximately $0.66 \%$ relative to $\mathrm{NO}_{3}{ }^{-}$production. Thus, it would be important to re-evaluate the global flux of $\mathrm{N}_{2} \mathrm{O}$ from forests from the perspective of changes in anthropogenic nitrogen emissions.

Acknowledgements We thank Y. Fang, S. Ohno, Y. Otsuka, Y. Aihara, F. Zhu, and K. Koba for help during field sampling and valuable discussion. This work was financially supported by a Grant-in-Aid for Scientific Research (21310008).

Open Access This article is licensed under a Creative Commons Attribution 4.0 International License, which permits use, sharing, adaptation, distribution and reproduction in any medium or format, as long as you give appropriate credit to the original author(s) and the source, provide a link to the Creative Commons licence, and indicate if changes were made. The images or other third party material in this article are included in the article's Creative Commons licence, unless indicated otherwise in a credit line to the material. If material is not included in the article's Creative Commons licence and your intended use is not permitted by statutory regulation or exceeds the permitted use, you will need to obtain permission directly from the copyright holder. To view a copy of this licence, visit http://creativecommons.org/licenses/by/4.0/.

\section{References}

Aber JD, Nadelhoffer KJ, Steudler P, Melillo JM (1989) Nitrogen saturation in northern forest ecosystems. Bioscience 39(6):378-286

Abbasi MK, Adams WA (2000) Gaseous N emission during simultaneous nitrification-denitrification associated with mineral $\mathrm{N}$ fertilization to a grassland soil under field conditions. Soil Biol Biochem 32(8):1251-1259

Baba M, Okazaki M, Hashitani T (1995) Effect of acid deposition on forested catchment in the western Tokyo, Japan. Water Air Soil Pollut 85(3):1215-1220

Bateman EJ, Baggs EM (2005) Contributions of nitrification and denitrification to $\mathrm{N}_{2} \mathrm{O}$ emissions from soils at different water-filled pore space. Biol Fertil Soils 41(6):379-388

Borken W, Beese F (2005) Control of nitrous oxide emissions in European beech, Norway spruce and Scots pine forests. Biogeochemistry 76(1):141-159

Bouwman AF, Boumans LJM, Batjes NH (2002) Emissions of $\mathrm{N}_{2} \mathrm{O}$ and NO from fertilized fields: summary of available measurement data. Glob Biogeochem Cycles 16(4):1-6

Bowden RD, Steudler PA, Melillo JM, Aber JD (1990) Annual nitrous oxide fluxes from temperate forest soils in the 
northeastern United States. J Geophys Res 95(D9):13997-14005

Breitenbeck GA, Blackmer AM, Bremner JM (1980) Effects of different nitrogen fertilizers on emission of nitrous oxide from soil. Geophys Res Lett 7(1):85-88

Bremner JM (1997) Sources of nitrous oxide in soils. Nutr Cycl Agroecosyst 49(1-3):7-16

Brumme R, Beese F (1992) Effects of liming and nitrogen fertilization on emissions of $\mathrm{CO}_{2}$ and $\mathrm{N}_{2} \mathrm{O}$ from a temperate forest. J Geophys Res 97(D12):12851-12858

Brumme R, Verchot LV, Martikainen PJ, Potter CS (2005) Contribution of trace gases nitrous oxide (N2O) and methane $(\mathrm{CH} 4)$ to the atmospheric warming balance of forest biomes. The Carbon Balance of Forest Biomes. Taylor \& Francis, London, pp 291-315

Castro MS, Steudler PA, Melillo JM, Aber JD, Millham S (1992) Exchange of $\mathrm{N}_{2} \mathrm{O}$ and $\mathrm{CH}_{4}$ between the atmosphere and soils in spruce-fir forests in the northeastern United States. Biogeochemistry 18(3):119-135

Cheng S, Wang L, Fang $\mathrm{H}$ et al (2016) Nonlinear responses of soil nitrous oxide emission to multi-level nitrogen enrichment in a temperate needle-broadleaved mixed forest in Northeast China. CATENA 147:556-563

Christiansen JR, Vesterdal L, Gundersen P (2012) Nitrous oxide and methane exchange in two small temperate forest catchments-effects of hydrological gradients and implications for global warming potentials of forest soils. Biogeochemistry 107(1-3):437-454

Dalal RC, Wang W, Robertson GP, Parton WJ (2003) Nitrous oxide emission from Australian agricultural lands and mitigation options: a review. Soil Res 41(2):165-195

De Boer W, Duyts H, Laanbroek HJ (1988) Autotrophic nitrification in a fertilized acid heath soil. Soil Biol Biochem 20(6):845-850

Dobbie KE, McTaggart IP, Smith KA (1999) Nitrous oxide emissions from intensive agricultural systems: variations between crops and seasons, key driving variables, and mean emission factors. $J$ Geophys Res 104(D21):26891-26899

Eickenscheidt N, Brumme R (2013) Regulation of $\mathrm{N}_{2} \mathrm{O}$ and $\mathrm{NO}_{\mathrm{x}}$ emission patterns in six acid temperate beech forest soils by soil gas diffusivity, $\mathrm{N}$ turnover, and atmospheric $\mathrm{NO}_{\mathrm{x}}$ concentrations. Plant Soil 369(1-2):515-529

Eickenscheidt N, Brumme R, Veldkamp E (2011) Direct contribution of nitrogen deposition to nitrous oxide emissions in a temperate beech and spruce forest-a ${ }^{15} \mathrm{~N}$ tracer study. Biogeosciences 8(3):621-635

Fang Y, Gundersen P, Zhang W et al (2009) Soil-atmosphere exchange of $\mathrm{N}_{2} \mathrm{O}, \mathrm{CO}_{2}$ and $\mathrm{CH}_{4}$ along a slope of an evergreen broad-leaved forest in southern China. Plant Soil 319(1-2):37-48

Galloway JN, Dentener FJ, Capone DG et al (2004) Nitrogen cycles: past, present, and future. Biogeochemistry 70(2): 153-226

Goreau TJ, Kaplan WA, Wofsy SC, McElroy MB, Valois FW, Watson SW (1980) Production of $\mathrm{NO}_{2}^{-}$and $\mathrm{N}_{2} \mathrm{O}$ by nitrifying bacteria at reduced concentrations of oxygen. Appl Environ Microbiol 40(3):526-532

Gundersen P, Callesen I, De Vries W (1998) Nitrate leaching in forest ecosystems is related to forest floor $\mathrm{CN}$ ratios. Environ Pollut 102(1):403-407
Gundersen P, Christiansen JR, Alberti G et al (2012) The response of methane and nitrous oxide fluxes to forest change in Europe. Biogeosciences 9(10):3999-4012

Hatch DJ, Jarvis SC, Parkinson RJ (1998) Concurrent measurements of net mineralization, nitrification, denitrification and leaching from field incubated soil cores. Biol Fertil Soils 26(4):323-330

Hirsch AI, Michalak AM, Bruhwiler LM, Peters W, Dlugokencky EJ, Tans PP (2006) Inverse modeling estimates of the global nitrous oxide surface flux from 1998-2001. Glob Biogeochem Cycles. https://doi.org/10.1029/ 2004GB002443

Hynes RK, Knowles R (1984) Production of nitrous oxide by Nitrosomonas europaea: effects of acetylene, $\mathrm{pH}$, and oxygen. Can J Microbiol 30(11):1397-1404

Inatomi M, Ito A, Ishijima K, Murayama S (2010) Greenhouse gas budget of a cool-temperate deciduous broad-leaved forest in Japan estimated using a process-based model. Ecosystems 13(3):472-483

IPCC (Intergovernmental Panel on Climate Change) (2001) Climate change 2001: the scientific basis. Cambridge University Press, Cambridge

IPCC (2007) Climate change 2007: the scientific basis. Cambridge University Press, Cambridge

Jones JM, Richards BN (1977) Effect of reforestation on turnover of ${ }^{15} \mathrm{~N}$-labelled nitrate and ammonium in relation to changes in soil microflora. Soil Biol Biochem 9(6):383-392

Kesik M, Ambus P, Baritz R et al (2005) Inventories of $\mathrm{N}_{2} \mathrm{O}$ and $\mathrm{NO}$ emissions from European forest soils. Biogeosciences 2(4):353-375

Killham K (1990) Nitrification in coniferous forest soils. Plant Soil 128(1):31-44

Kimura SD, Saito M, Hara H, Xu YH, Okazaki M (2009) Comparison of nitrogen dry deposition on cedar and oak leaves in the Tama Hills using foliar rinsing method. Water Air Soil Pollut 202(1-4):369-377

Klemedtsson L, Von Arnold K, Weslien P, Gundersen P (2005) Soil $\mathrm{CN}$ ratio as a scalar parameter to predict nitrous oxide emissions. Glob Change Biol 11(7):1142-1147

Kroeze C, Mosier A, Bouwman L (1999) Closing the global $\mathrm{N}_{2} \mathrm{O}$ budget: a retrospective analysis 1500-1994. Glob Biogeochem Cycles 13(1):1-8

LeBauer DS, Treseder KK (2008) Nitrogen limitation of net primary productivity in terrestrial ecosystems is globally distributed. Ecology 89(2):371-379

Liu L, Greaver TL (2009) A review of nitrogen enrichment effects on three biogenic GHGs: the $\mathrm{CO}_{2}$ sink may be largely offset by stimulated $\mathrm{N}_{2} \mathrm{O}$ and $\mathrm{CH}_{4}$ emission. Ecol Lett 12(10):1103-1117

Lovett GM, Goodale CL (2011) A new conceptual model of nitrogen saturation based on experimental nitrogen addition to an oak forest. Ecosystems 14(4):615-631

Maag M, Vinther FP (1996) Nitrous oxide emission by nitrification and denitrification in different soil types and at different soil moisture contents and temperatures. Appl Soil Ecol 4(1):5-14

Mathieu O, Hénault C, Lévêque J, Baujard E, Milloux MJ, Andreux F (2006) Quantifying the contribution of nitrification and denitrification to the nitrous oxide flux using ${ }^{15} \mathrm{~N}$ tracers. Environ Pollut 144(3):933-940 
McSwiney CP, McDowell WH, Keller M (2001) Distribution of nitrous oxide and regulators of its production across a tropical rainforest catena in the Luquillo Experimental Forest. Puerto Rico Biogeochemistry 56(3):265-286

Morishita T, Sakata T, Takahashi M et al (2007) Methane uptake and nitrous oxide emission in Japanese forest soils and their relations to soil and vegetation types. Soil Sci Plant Nutr 53(5):678-691

Morishita T, Aizawa S, Yoshinaga S, Kaneko S (2011) Seasonal change in $\mathrm{N}_{2} \mathrm{O}$ flux from forest soils in a forest catchment in Japan. J For Res 16(5):386-393

Nishina K, Takenaka C, Ishizuka S (2009) Spatiotemporal variation in $\mathrm{N}_{2} \mathrm{O}$ flux within a slope in a Japanese cedar (Cryptomeria japonica) forest. Biogeochemistry 96(1-3):163-175

Ohrui K, Mitchell MJ (1997) Nitrogen saturation in Japanese forested watersheds. Ecol Appl 7(2):391-401

Osaka KI, Ohte N, Koba K, Katsuyama M, Nakajima T (2006) Hydrologic controls on nitrous oxide production and consumption in a forested headwater catchment in central Japan. J Geophys Res. https://doi.org/10.1029/ 2005JG000026

Perakis SS, Sinkhorn ER (2011) Biogeochemistry of a temperate forest nitrogen gradient. Ecology 92(7):1481-1491

Pilegaard K, Skiba U, Ambus P, Beier C, Pihlatie M, Vesala T (2006) Factors controlling regional differences in forest soil emission of nitrogen oxides ( $\mathrm{NO}$ and $\mathrm{N}_{2} \mathrm{O}$ ). Biogeosciences 3(4):651-661

Pitcairn CER, Skiba UM, Sutton MA, Fowler D, Munro R, Kennedy V (2002) Defining the spatial impacts of poultry farm ammonia emissions on species composition of adjacent woodland groundflora using Ellenberg Nitrogen Index, nitrous oxide and nitric oxide emissions and foliar nitrogen as marker variables. Environ Pollut 119(1):9-21

Schmidt J, Seiler W, Conrad R (1988) Emission of nitrous oxide from temperate forest soils into the atmosphere. J Atmos Chem 6(1-2):95-115

Shindell DT, Faluvegi G, Koch DM, Schmidt GA, Unger N, Bauer SE (2009) Improved attribution of climate forcing to emissions. Science 326(5953):716-718

Skiba U, Sheppard LJ, Pitcairn CER, Van Dijk S, Rossall MJ (1999) The effect of $\mathrm{N}$ deposition on nitrous oxide and nitric oxide emissions from temperate forest soils. Forest Growth Responses to the Pollution Climate of the 21st Century. Springer, Amsterdam, pp 89-98

Skiba U, Ball B (2002) The effect of soil texture and soil drainage on emissions of nitric oxide and nitrous oxide. Soil Use Manag 18(1):56-60

Skiba U, Smith KA (2000) The control of nitrous oxide emissions from agricultural and natural soils. Chemosphere Glob Change Sci 2(3-4):379-386

Stevens RJ, Laughlin RJ, Burns LC, Arah JRM, Hood RC (1997) Measuring the contributions of nitrification and denitrification to the flux of nitrous oxide from soil. Soil Biol Biochem 29(2):139-151

Tortoso AC, Hutchinson GL (1990) Contributions of autotrophic and heterotrophic nitrifiers to soil $\mathrm{NO}$ and $\mathrm{N}_{2} \mathrm{O}$ emissions. Appl Environ Microbiol 56(6):1799-1805

Venterea RT, Groffman PM, Verchot LV, Magill AH, Aber JD (2004) Gross nitrogen process rates in temperate forest soils exhibiting symptoms of nitrogen saturation. For Ecol Manag 196(1):129-142

Vitousek PM, Howarth RW (1991) Nitrogen limitation on land and in the sea: how can it occur? Biogeochemistry 13(2):87-115

Vitousek PM, Gosz JR, Grier CC, Melillo JM, Reiners WA (1982) A comparative analysis of potential nitrification and nitrate mobility in forest ecosystems. Ecol Monogr 52(2):155-177

WMO (World Meteorological Organization) (2015) Greenhouse Gas Bulletin: The State of Greenhouse Gases in the Atmosphere Based on Global Observations through 2014

Yoh M, Konohira E, Yagi K (2001) Regional distribution of natural stream nitrate in central Japan. Water Air Soil Pollut 130(1-4):655-660

Zhang JB, Zhu TB, Cai ZC, Qin SW, MÜller C (2012) Effects of long term repeat mineral and organic fertilizer applications on soil nitrogen transformations. Eur $\mathrm{J}$ Soil Sci 63(1):75-85

Publisher's Note Springer Nature remains neutral with regard to jurisdictional claims in published maps and institutional affiliations. 